\title{
Future Trends in Language Intervention: Addressing Cultural Bias in Service Delivery*
}

\author{
Anne van Kleeck \\ Professor \\ Program in Communication Sciences and Disorders \\ Department of Speech Communication \\ University of Texas at Austin \\ Austin, Texas 78712 \\ USA
}

\begin{abstract}
In this paper the cultural biases in a widely-used language intervention approach - the Hanen Early Language Parent Program - that trains parents to be conversational partners with their language-delayed children, are explored. In many respects this program represents the best of current clinical practice. It is empirically and theoretically grounded in recent research on parent-child interaction; studies have documented its efficacy; and it is a family-centred approach. And yet, in clinical practice, it does not work with all families. Not surprisingly, these families are often from nonmainstream backgrounds. Potential reasons for the lack of effectiveness with some families become apparent as research on patterns of language socialization in a wide variety of cultures is reviewed. This review reveals that all of the basic premises of this program rest on culturally relative beliefs and values. Specifically considered are cultural variation in (1) aspects of social organization related to interaction, (2) the value of talk, (3) how status is handled in interaction, (4) beliefs about intentionality, and (5) beliefs about teaching language to children. Suggestions for incorporating this information into clinical services with nonmainstream families are offered.
\end{abstract}

\section{OPSOMMING}

Die kulturele bevooroordeling van die "Hanen Early Language Parent Program" word ondersoek. Hierdie program is tans algemeen in gebruik en verteenwoordig die beste in huidige kliniese riglyne. Dit is 'n taalopleidingsbenadering wat ouers oplei as gespreksgenote vir hul kinders met vertraagde taalverwenuing. Die program is empiries en teoreties gebaseer op onlangse navorsing in ouer-kindinteraksie; verdere studies lewer bewys van die effektiwiteit van dié program; en dit is 'n gesinsgesentreerde benadering. Kliniese gebruik van die program dui egter da a rop dat dit nie op gesinne buite die hoofstroomagtengrond, van toepassing is nie. Potensiële redes vir die gebrek aan effektiwiteit met sekere gesinne word uitgelig, wanneer die patrone van taalsosialisasie van verskillende kulture nagegaan word. Die gevolgtrekking word gemaak dat die basiese grondbeginsels van hierdie program op kultuur verwante waardes en beginsels berus. Kulturele verskille bestaan, veral ten opsigte van (1) aspekté van sosiale organisasie wat verband hou met interaksie, (2) die waarde van:gesprek, (3) hantering van status in interaksie, (4) beginsels ten opsigte van intensionaliteit en (5) waardes aangaande taalopleiding vir kinders. Voorstelle word gemaak vir die implimentering van hierdie inligting in die dienslewering aan nie-hoofstroom gesinne.

When I entered the field of Communication Disorders as an undergraduate in 1970 , we called ourselves speech pathologists. We had no courses on children's language development or language disorders. Indeed, language had not yet entered our realm. In the Fall of 1973 , I entered a masters program at Columbia University and there met Lois Bloom. Lois had been a practising speech-pathologist for a number of years and was inspired to do doctoral work because her clinical experience had led her to the realization that there was more to children's communication disorders than their difficulties with speech. When I met her, she had just published her pioneering work, Language Development: Form and Function in Emerging Grammar (1970). Other than some diary studies done by linguist

\footnotetext{
* This paper was delivered as the Sixth P. de V. Pienaar Memorial Lecture held in the Senate House, University of Witwaterstand, on $20 \mathrm{July} 1992$.
}

parents, it was one of the very first in depth, comprehensive studies of early language development. Her work, along with that of psychologist Roger Brown (1973) among others, was to revolutionize the field of communication disorders by adding language to its purview. The national association of professionals in communication disorders in the United States was renamed in 1977 to reflect this change - the American Speech and Hearing Association became the American SpeechLanguage-Hearing Association.

Now, twenty years later, I sometimes find myself in absolute awe at how far we have come in our understanding of children's language development and language disorders. There are now dozens of journals and hundreds of books devoted, in part or full, to scholarship in this area. Armed with the vast amount of knowledge spawned by twenty years of vigorous research and clinical practice, we are more effective than ever in assisting children who have difficulty in acquiring that most basic and 
essential of human capacities - language.

I like to remind myself from time to time of this rich and rewarding history, of how far we have come, and of how much better we are currently doing. I like to remind myself because it helps balance another feeling that frequently surfaces - that of being overwhelmed. Overwhelmed because, as we learn more, the task of pulling that knowledge together into a cohesive whole becomes increasingly daunting. And clinical practice that does not at least attempt to deal with the whole, is, in my opinion, completely missing the mark. I feel overwhelmed, too, because as we learn more, we simultaneously become aware of how much more we need to understand. The complexity seems to multiply exponentially. One is never allowed to rest, it seems, with knowledge hard-gained.New issues continually beg attention: and, because we care about providing the very best service delivery, we cannot ignore them.

I'd like to focus my talk today on an issue, or rather, a complex set of issues, that began as an uncomfortable stirring for me about three years ago. It is only recently, however, that the faint rumblings of something being amiss in my thinking has worked its way into a more conscious awareness of what might lie at root. Let me provide a little background.

In 1989, I was awarded a training grant by the United States Department of Education to prepare specialists to work with handicapped infants and toddlers and their families. These funds were made available to fill a need created by a federal law passed in 1986, Public Law 99-457 (now P.L. 101-476), which mandated that states put in place a plan to provide services to families with handicapped children from birth to three years of age. Previous legislation (Public Law 94-142) had required services for children above three years of age. Public Law 99-457 further specified that services must be familycentered, meaning that families would not only be closely involved in all assessment and intervention, but that they would also determine priorities for their child's services. They would, in effect, be equal team members. To work effectively with families, a clinician must respect individual family structure and interaction patterns. To do so, the need for cultural sensitivity becomes glaringly apparent.

As I have worked with my grant project director, Ann Thomas, in developing course work and in setting up an infant/ toddler assessment team in our university clinic, I have come to realize that implementing family-centered services may be difficult for deeper reasons than the mere fact that change is always difficult. For me, the process of implementing familycentered services has forced into consciousness some points at which the values of our mainstream culture, of our profession, and of family-centered services for nonmainstream families may be in conflict. If we are to take the next step in providing even more efficacious services, we need to grapple openly with these sources of conflict. Resolving these conflicts will hopefully result in changes that not only acknowledge the complexity posed by cultural diversity, but begin to offer more concrete guidance for our thinking about language assessment and intervention with children from non-mainstream families. Given the multicultural nature of both of our societies, this issue seems as relevant to South Africa, in essence if not in details, as it is to the United States.

The mainstream cultural values in the United States that are particularly relevant to the discussion at hand include (a) the high value placed on verbal/literate skills, (b) our democratic ideal of equal opportunity for all, beginning with equal access to education and extending to maximizing the potential for upward mobility of all citizens, and (c) the value placed on individual choice. As we translate these cultural values into professional values, we find (a) a high value placed on facilitat- ing the very "best" verbal/literate skills possible in all children we serve, and (b) that our notion of "best" is determined by those skills we know will foster the best chances for academic success, and, by implication, for lifelong success. The introduction of family-centered services addresses the third cultural value of individual choice - families should be able to choose not only the kind of services they prefer from all options available, they should also have the final word on the goals to be focussed upon and the procedures that should be used to facilitate reaching those goals.

A current, widely used intervention program reflects these values directly. First of all, it rests on the basic premise that one should attempt to get children to be as communicative as possible. The adult-child interaction patterns determined in research to best foster children's communicative attempts and subsequent language development provide the basis of the program. And finally, it is family-centered in that the interaction patterns are directly taught to the language delayed child's parents. The program, the Hanen Early Language Parent Program, was developed by Ayala Manolson in Toronto, Canada (1985). I'd like to focus on the Hanen program to illustrate the pressing need for speech-language pathologists to become aware of the cultural biases it entails. This is not done to denigrate this program - we have used it fruitfully in our clinic for years. The program is focussed on exactly because it does, in my mind, represent the best of current clinical practice. A careful analysis of the program's underlying cultural biases, however, uncovers dramatically the need for far more cultural sensitivity in our clinical practice than is presently the norm.

The Hanen Early Language Parent Program is based largely on the clinical work of Jim MacDonald, who in turn has grounded his ideas in an ever-growing body of basic research on adult-child interaction (e.g., MacDonald, 1989). This program works directly with the parents (both mother and father whenever possible) to foster the interaction patterns within the family that will promote communication development. It is aimed at parents of children who are either preverbal or at the earliest stages of verbal development. Several sets of parents are brought together in weekly three-hour meetings for eight to ten weeks. Program objectives are taught via workbooks, lectures, demonstrations, training videotapes, videotapes of the parents in the group interacting with their own children, group discussion, role playing and homework assignments. To make the current videotapes, all parents enrolled in the program are videotaped at home interacting with their own children at three different junctures - once before, once during and once after the program - so that specific implementation can be discussed. The interaction strategies are based upon those that research has found (1) to best promote language development, and (2) to be lacking or infrequent in the interaction of parents with their language delayed children. The strategies are focussed one at a time, and include, sequentially, observing your child (to accurately assess the child's current communication level), following your child's lead (including talking at his or her level), responding supportively to the child's a ttempts at communication, fostering the child's turn-taking skills, prompting the child to a higher level of communicative performance, and designing play activities to provide communication opportunities (see Girolometto, Greenberg, \& Manolson, 1986, for further program description and a summary of supporting research).

When I was first trained in this program by Ayala Manolson several years ago, I felt that the field of speech-language pathology was finally beginning to implement practices that took into account far more of the complex puzzle of factors that are involved in a child's language development. This direct work 
with parents on the interactional foundation for language development was a far cry from the behavior modification programs that permeated the field in the 1970's, when clinician's were busy "flipping pictures and pitching tokens" (Constable, 1986 , p. 211) in pursuit of that elusive "is verb-ing" form. It also moved us beyond the subsequent application of the semantic and pragmatic revolutions when we were attempting to create meaningful contexts in our therapy rooms, but were not yet fully acknowledging that children are a part of a family system. Hanen, and programs like it, have provided a much needed family-centered option for facilitating language development. A systematic clinical tool, it fosters parent-child interaction patterns that encourage children's communicative behavior and, consequently, their communicative development.

The Hanen Program is well grounded both theoretically and empirically, and is often very effective. However, in our clinical experience, it does not work with all families. Not surprisingly, these families are often from minority cultures. Why doesn't it work? Perhaps because many nonmainstream cultural values and beliefs that impact interaction patterns are at odds with those the Hanen program attempts to foster. Indeed, the empirical and subsequent theoretical underpinnings of the Hanen program are based in large part on North American psycholinguistic research that has focussed almost exclusively on the white middle class. This fact is often unmentioned in these studies, a phenomenon Ochs and Schieffelin (1984) refer to as "the invisible" culture of child language studies. Because the cultural biases of these studies have remained largely implicit, we have often assumed they illuminate natural rather than cultural behaviors (Ochs \& Schieffelin, 1984, p. 284).

In the following discussion, patterns of language socialization in a wide variety of cultures will be explored.In particular, I will consider cultural relativity regarding (1) aspects of social organization related to interaction, (2) the value of talk, (3) how status is handled in interaction, (4) beliefs about intentionality, and (5) beliefs about teaching language to children. As will be seen in this discussion, all of the basic premises of the Hanen Program rest on culturally relative social organization, beliefs, and values.

\section{Social Organization Issues Related to Interaction}

The Hanen Program makes two basic asssumptions about social organization that impact on both how and with whom interaction with young children occurs. The first assumption is about caregiving, which impacts "who talks to small children, in what contexts, and about what topics" (Schieffelin \& Eisenberg, 1984, p. 387). The Hanen Program is a parent program. It assumes that the young child's parents are the primary caregivers. However, caregiving arrangements vary in different cultures. In many cultures, siblings are the primary caregiver, particularly after the baby to be cared for has become mobile. This is true, for example, among the Western Samoans (Ochs, 1982), the Kikuyu of eastern Africa (Leiderman \& Leiderman, 1974), the Gusii of Kenya (LeVine \& LeVine, 1966). It is also common in many American subcultures, including Hawaiian, Native American, Black, and MexicanAmerican and other Hispanic communities (Werner, 1984). The Hanen Program focus on parent interaction skills would clearly be of less value in such cultures.

A second assumption of the Hanen. Program related to social organization has to do with turn-taking. The Hanen Program assumes that interaction with young children will be primarily dyadic, a predominant pattern in mainstream Western culture. However, multiparty interaction dominates in many cultures - for example, with the Basotho (Demuth, 1986), the Kaluli (Schieffelin, 1979), the Samoans (Ochs, 1982), and Mexican-Americans (Briggs, 1984; Eisenberg, 1982).

\section{Value of Talk}

Let's consider the basic cultural value that undoubtedly accounts for the very existence of speech-language pathology the value of talk. To consider different cultural perspectives on the value of talk, I'd like to look at (1) the amount of talk that is valued, (2) the role of talk in teaching in general, (3) the relative value of verbal skills compared to other types of skills, and (4) the role of verbal skills in children's display of knowledge.

1 - Amount of talk. Regarding amount of talk, a fairly high degree of verbosity in children is valued in our mainstream culture. Indeed, an entire line of social science research views reticence as a social deficiency (see Daly \& McCroskey, 1984), and points out the negative perceptions held in our culture toward reticent children and adults alike. For example, as compared to their more talkative peers, reticent children are viewed by their teachers as significantly less likely to do well in all academic areas and less likely to have positive relationships with other students (McCroskey \& Daly, 1976). Indeed, quietness in the classroom may lead to a speech-language pathology referral. Crago (1990b) reports of a principal who was asked to compile a list of children who had speech and language problems. Of the 90 children in her school, she listed 30 names and next to several of them noted, "Does not talk in class" (p. 79).

Because mainstream adults value children's talk, they work to elicit it during interactions with children. This mainstream value is sometimes held in other cultures as well. Bambi Schieffelin studied a traditional nonliterate people in Papua New Guinea, the Kaluli, and found that adults in that society also believed it important to elicit speech from children (Schieffelin \& Eisènberg, 1984). The Basotho also highly regard children's ability to interact with others. "Indeed, teaching one's child how to talk is seen as one of the major responsibilities of mothers, other caregivers, and the community at large" (Demuth, 1986, p. 54). A Sesotho proverb loosely translated as "A quiet person will perish" captures the importance of verbal ability in this society (Demuth, 1986). Such a view is clearly not universal, however. In the working class Black community studied by Heath (1983), the adults did not ask children questions in order to keep the conversation going, nor did they consider children to be appropriate conversational partners. Ward (1971) describes her early attempts at data collection in another Black community in rural Louisiana. "For the first two months of this project attempts to elicit spontaneous speech from the children met with defeat, with or without the tape recorder. The readiness to show off, the constant flow of speech, the mother-child interaction so common in middle-class children were nowhere in evidence. The children appeared to speak as little to their parents as to the investigator. One twenty-eight month male spoke three words in as many months" ( p. 15). Quite to the contrary of our mainstream pattern of socializing children to interact with adults, many cultures value quietness in children. Many groups believe that children should speak only when spoken to, such as the Kipsingis (Harkness, 1977) and Luo (Blount, 1972;1977) of Kenya, Western Samoans (Ochs, 1982), and the Tamil of Malaysia (Williamson, 1979). And this is true not only in nonindustrialized or third world cultures - but in many North American sub-cultures that have been studied as well, such as rural Louisiana Blacks (Ward, 1971) and many American Indian groups (Crago, 1990b; Dumont, 1972; John, 1972; 
Scollon \& Scollon, 1981). Furthermore, children in many groups are often socialised to a generalised attitude regarding the value of silence. For example, the Japanese (Clancy, 1986; Fischer, 1970) and other Asian/Pacific groups (see Cheng, 1989 , for a summary), who have immigrated to the United States in vast numbers in the past decade, often view a quiet child as a good child. This value is also held by the evergrowing Chicano population in the United States, as well (Coles, 1977). In many Native American cultures, children are taught to be silent in the presence of an adult, especially an unfamiliar adult (Blanchard, 1983). Indeed, Navajo mothers view loquaciousness in a child as discourteous, self-centered, and undisciplined (Freedman, 1979). The extreme variation in the value of talk even within the American culture is dramatically illustrated in a study conducted by Birdwhistell (1974). He compared the median amount of talk per day in Philadelphia Jewish homes and in Pennsylvania Dutch homes (an agricultural group that has eschewed modern technology). The Jewish families talked between six and twelve hours a day; the Pennsylvania Dutch, for two and one half minutes! From a rather different perspective, the Scollons provide an example of the extreme differences in cultural expectations regarding children's talk. Among the Northern Canadian Athabaskans they studied, "children who do not begin to speak until five years of age or older are interpreted as growing up respectfully, not as being 'language-delayed' "(Scollon \& Scollon, 1981, p. 134). Indeed, our profession's very definition of a learning disability is stood upon its head in the comment made by an Inuit teacher in Martha Crago's study. One of Crago's research subjects was a very verbal little boy, whom she considered to be very bright. Crago described this child to an Inuit teacher and asked her reaction. The teacher said, "Do you think he might have a learning problem? Some of these children who do not have such high intelligence have trouble stopping themselves. They don't know when to stop talking" (Crago, 1990b, p. 80).

Of course, social values associated with the talkative-reticence continuum are not as clear cut as this discussion might imply. The Scollons (1981) discuss how the degree of volubility and degree of intimacy are related in an opposite fashion in North American mainstream and Native Athabaskan cultures. For mainstream speakers, they suggest, volubility is associated with social distance and taciturnity is acceptable in intimate relationships (that talk is not needed may indeed be a sign of intimacy). For the Athabaskans, the opposite is true. They can be very talkative when they know each other well, but are quite reticent with people they have just met.

2 -How teaching is accomplished. Because our mainstream culture values talk, teaching is often accomplished with a great deal of talk. Heath (1989) describes how mainstream adults engage in frequent verbal explanation with children. They intervene in a task being taught to offer step-by-step explanations, and children are afterwards often asked to recount the task verbally. Such a teaching style is typical of what Hall (1976) refers to as "low-context cultures". In contrast, "highcontext" cultures rely much more heavily on the physical context, and hence nonverbal contextual cues, to convey information. Learning is accomplished primarily by observation; teaching by demonstration. Westby and Rouse (1985) note that Hispanic and Native American groups in the United States operate much more as high-context cultures in comparison to the Anglo mainstream culture. Children in lowcontext cultures are encouraged to ask questions; those in more high-context cultures are not. In specific studies, Ward found that children's information-seeking questions were ignored among the rural Louisiana Blacks she studied (1971), and the Inuit children studied by Crago were also discouraged from asking questions (1990).

3 - Skills valued. Heath (1989) ties a tendency to teach by demonstration with "societies that marshal children's efforts toward spatial, kinesthetic, musical, and interpersonal competence as prior or at least of equal merit with linguistic competence" (p. 342). So, once again, verbal skills are not always valued above all else, as they often seem to be in our mainstream culture.

4 - Display of knowledge. A final aspect of the value of talk within a given culture has to do with how knowledge is displayed, and by whom. Scollon and Scollon (1981) discuss the dimensions of spectatorship/exhibitionism in relation to dominant and subordinate roles. They explain how in our mainstream culture, the dominant person is the spectator and the subordinate person the exhibitionist. As such, the notion of display of knowledge is related to how status is handled in a culture, a topic I will discuss in the next section. In other cultures, such as the Athabaskans the Scollons studied, the dominant person is the exhibitionist rather than the spectator.

In our mainstream culture, adults often elicit verbal displays of knowledge from their children. They often do this by asking children questions to which they, the adults, already have the answers. The children are nonetheless expected to perform their "exhibitionist" role and respond to these known-information or, as they are sometimes called, "test" questions. This verbal display of knowledge figures predominantly in the school setting as well. In many other cultures, requesting children's verbal display of knowledge is either not used or is used for different purposes. Heath (1983) found that the adults in the Black working class community she studied only rarely asked known information questions. When they did, the purpose was to chastise the child. Heath (1989) summarizes several unpublished studies of MexicanAmerican showing that adults refrain from asking children known-information questions, except in teasing exchanges. Other groups not prone to using test questions in interaction with their children include the Inuit studied by Crago (1990b) and the rural Louisiana Blacks studied by Ward (1971). Ward, in fact notes, "Such children are not expected to exhibit any range of manners, skills, or special knowledge" (p. 53). In these various nonmainstream cultures, children are expected to be spectators and learn by observation.

\section{How Status is Handled in Interactions}

In the Hanen Program we ask parents to respond to all the child's attempts to initiate interaction, to follow the child's lead to facilitate conversation, to use simple language and to expand the child's communicative attempts so that the child will have the opportunity to learn from responses, and to use questions to confirm or clarify. Each of these suggestions rests upon underlying assumptions - assumptions not always shared by other cultural groups. Let's consider them by looking at how various cultures deal with (1) who initiates adultchild interaction, (2) who directs adult-child interaction, (3) who adapts to whom, and (4) who carries the burden of understanding.

1 - Who initiates adult-child interaction. In mainstream culture, while adults are certainly allowed to initiáte interaction with children, children are also encouraged to initiate interaction with adults. We witness this primarily by observing how responsive adults are to children's initiations, intentional or otherwise. Indeed, researchers have written entire articles on the positive impact of caregiver contingent social responsiveness to infants on their children's subsequent 
subsequent acquisition of communicative competence (e.g., Dunst, Lowe, \& Bartholomew, 1989-90; Goldberg, 1977). But once again, this is clearly not a universal phenomenon. The rural Blacks studied by Ward (1971) paid more attention to a child when the child was not talking than when she or he was. In the Black community studied by Heath (1983), the adults did not tend to ask many questions in order to keep an interaction going with a child. Indeed, these minority cultures and others, such as Mexican-Americans (discussed by Heath, 1989), do not believe that a child should initiate a conversation with an adult. Some cultures, such as the Japanese, will even anticipate a child's needs in order to foster passivity (Caudill \& Weinstein, 1969).

2 - Who directs the interaction. It is often the case that the person who initiates an interaction also directs it. Schegloff (1972), for example, found that the person who speaks first in a conversation also tends to control the topic. Likewise, in mainstream parent-child interaction, the parent follows the child's lead. In other words, the adult talks about what the child is doing or saying. Snow refers to this as semantic contingency, and reviews numerous studies providing evidence that this interaction strategy facilitates language acquisition $(1979,1981)$. The temporal characteristics of contingent responses are also important, as has been demonstrated in work with mother-infant dyads. Numerous studies have found that most maternal responses to infant vocalizations occur within one second (Beebe, Jaffe, Feldstein, Mays, \& Alson, 1985; Schaffer, Collis \& Parsons, 1977; Stella-Prorok, 1983) and that response delays of longer than one second interfere with the infant's perception of contingent relationships (Millar, 1972; Millar \& Watson, 1979; Ramey \& Ourth, 1971; Todd \& Palmer, 1968). Temporal delays in adults' responses have also been found to completely disrupt conversations with 2-year-olds, because the children stopped responding (Stella-Prorok, 1983). Obviously, both semantic contingency and such a quick response requires careful attention to the infant by the adult.'

Other cultures do not allow children to direct topics (e.g. rural Louisiana Blacks studied by Ward, 1971), and may believe it is the adult's role to issue directives and the child's role to obey them (Louisiana Blacks, the Inuits studied by Crago, $1990 \mathrm{~b}$ ). In many societies, parent-child interaction is not characterized by adult semantic contingency. This is true of the Westein Samoans (Ochs \& Schieffelin, 1984), the Kaluli (Schieffelin \& Eisenberg, 1984); the Gusii of Kenya (LeVine, 1977), and rural Louisiana and Carolina Blacks in the United States (Heath, 1983; Ward, 1971).

3 -Who adapts to whom: Assuming the perspective of the child in making semantically contingent responses is one way in which mainstream parents make rather extensive accommodations to the child. Such accommodations are in part determined by how status is handled in a culture. In our mainstream culture, persons of higher status are expected to adapt to those of lower status - hence, adults adapt to children. As Ochs and Schieffelin (1984) note, it is a pattern that extends beyond adult-child interactions and is also observed in widespread material accommodations, such as baby clothes and

\footnotetext{
1 The Scallons (1981) discuss one instance of timing differences in interaction - that between the Athabaskans they studied and North American mainstream culture. The pause time between turns in conversation is slightly longer for Athabaskans, although perhaps only a half second longer. The impact on interaction between these two groups, however, is dramatic. The mainstream speakers give adequate pauses for the other to take a turn within their own culture but it is not long enough for the Athabaskan culture. Hence, the mainstream speakers do all the talking and the Athabaskan never gets a chance.
}

food, and miniaturization of furniture and toys. Additional common behavioral accommodations include "baby-proofing" a home, and putting the baby in a quiet place to facilitate sleep. These scholars suggest that "these accommodations reflect a discomfort with the competence differential between adult and child" (p. 287). In interaction, one way that this competence gap is reduced is for the adult to simplify his or her speech to better match the lesser verbal competence of the child. This simplified speech is known by many names "motherese" (Newport, Gleitman, \& Gleitman, 1977), "baby talk register" (e.g., Brown, 1977), and "child-directed talk (CDT)" (van Kleeck \& Carpenter, 1980) or "child-directed speech (CDS)"'(Snow, 1986). This simplified, reduced, redundant, acoustically distinct input to young children has been extremely well-documented in a variety of middle-class industrialized cultures (see Snow, 1986, for a review that relates this simplified register to language acquisition). Fischer (1970) notes that the Japanese parents seem even more disposed to these speech simplifications than mainstream Americans. But such modifications are not solely found in modern, industrialized societies. They have been found to characterize parent-child interactions among the Kipsingis in Kenya (Harkness, 1977) and the Kwara'ae of the Solomon Islands (Watson-Gegeo \& Gegeo, 1986a \& b).

In other cultures, persons of lower status are expected to adapt to those of higher status. This particular cultural value may be manifested in interactions with infants and young children by a lack of child-directed talk simplifications on the part of adults. This is the case with the Western Samoans studied by Ochs (1982). Heath also found a lack of such adult adaptation in the working-class Black community she studied (Heath, 1983)

It is not simply the case that CDT modifications are either present or absent in most cultures. Schieffelin and Ochs (1986) discuss how there is a continuum 'of accommodation both across and within cultures. Within cultures, variability in the existence or degree of CDT modifications may occur as a function of who is talking to the child, the reason for the interaction, the setting, and the development level of the child. In mainstream American culture, some studies have documented that fathers and siblings do not simplify their talk to babies as much as mothers do (e.g., Andersen \& Kekelis, 1986; Bellinger \& Gleason; 1982; Gleason \& Greif; 1983; Mannle \& Tomasello, 1987). A study by Gollinkoff and Ames (1979), however, found that fathers did adjust their speech as much as mothers although they produced half as many utterances and took fewer turns in a free play situation. In Japan, mothers simplify far more in private than they do in public (Clancy, 1986). The Basotho use such modifications when their intent is to amuse or pacify the infant or young child, but they do not use them when talking seriously or reprimanding (Demuth, 1986). The Luo make no such modifications from birth until about 9 months of age, then make them extensively until the baby's first word at about 14 months. After 14 months, they are used to get attention, but not after attention has been gained (Blount 1972).

4 - Who carries the burden of understanding. Lacking an adult facility with the linguistic system, children are frequently difficult to understand. As with other accommodations, mainstream adults have strategies to attempt to deal with an unintelligible or partially intelligible child. They may ask clarification questions (e.g., Sachs, 1983) or they may expand the child's utterances. Brown (1977) suggests that expansions are communication checks that in effect ask the child, "Is this what you mean by what you just said?" (p. 13). Wells (1982) offers a different interpretation of expansions. Wells found 
that expansions in mother-child interaction were contextually determined. They rarely occurred when the dyad was alone, but were frequent when the mother-child dyad was in a group. The expansions seemed to serve as a way of explaining to others outside the mother-child dyad what the child might be intending to say. In either case, it is clearly the adult who carries the burden for making the child understood.

Ochs and Schieffelin (1984) explain how status is handled differently among the Western Samoans. Here persons of lesser status have the responsibility for making themselves clear. As such, adults do not expand children's utterances. A lack of expansions in adults' speech to children has been found in other cultures, as well, including the rural Louisiana Blacks studied by Ward (1971) and the Kipsingis of Kenya studied by Harkness (1977). Interestingly, while mothers in Ward's study did not imitate or expand the speech of their children, they did repeat and expand their own speech.

\section{Beliefs about Intentionality}

Some components of the Hanen Program rest on cultural assumptions about intentionality. Parents in the program are asked to freely interpret a child's intended meanings and provide labels for preverbal children and expansions for children in the early stages of language development. Let's look at the assumptions underlying these suggestions regarding (1) other intentions and (2) when intentionality begins.

1 - Others intentions. Many behaviors characteristic of mother-child interaction in American mainstream culture make it appear that adults in our culture believe that one person can interpret another's intentions. Mothers often interpret internal states of infants as they engage in "conversation" with them (e.g., Snow, 1977). With older children, nonconventional forms are often accepted as words, and mothers often provide the label they believe the child is intending to produce. Indeed, this occurs with many unintelligible or partially intelligible utterances (Ochs, 1982). Not all cultures however, believe that one can know what another thinks or feels. Ochs and Schieffelin (1984) discuss this as underlying the lack of adult interpretation or expansions of children's communicative attempts among the Kaluli. It is interesting to note that this same adult behavior, a lack of expansions, can stem from two quite different sources. Recall that the Samoans, also discussed by Ochs and Schieffelin, did not expand children's utterances for status reasons.

2 - When intentionality begins. Cultures also vary regarding when they begin treating children as intentional. In our mainstream culture, we treat children as intentional from birth. This is done by engaging the infant in "conversational dialogue", often by interpreting prelinguistic behaviors (e.g., Lock, 1981; Ryan, 1974; Shotter, 1978). Such social "conversations" are common from birth among the Kwara'ae as well. However, they are clearly not universal. Among the Northern New Mexico Hispanics studied by Briggs (1984), a child is not treated as intentional until she or he is one year of age. A similar type of pattern among Mexican-American families in California was noted by Eisenberg (1982). In Western Samoa, sibling caregivers begin treating babies as intentional once the baby is mobile (Ochs, 1988). Neither the Kaluli of Papua New - Guinea (Ochs \& Schieffelin, 1984), the Luo (Blount, 1972), nor American Blacks studied by Heath (1983) direct much input to prelinguistic babies. Navajo mothers are silent with their infants (Freedman, 1979).

\section{Language Teaching Beliefs}

The Hanen Program clearly espouses engaging young prelinguistic and beginning language users in a conversation-like exchange which is structured so that the child can be an "equal" participant. The goal is to get children to communicate as frequently as possible, but directive techniques for eliciting language are strongly discouraged.Fostering equal participation in a conversation as a method of facilitating language acquisition is also a culturally determined phenomenon. In addition to conversation, other culturally sanctioned methods of facilitating language acquisition include direct teaching by eliciting imitations from children and a "look and listen" approach in which children are expected to learn by observation.

Direct teaching. The use of direct teaching as a general method of facilitating language acquisition is actually a fairly widespread phenomenon, found both in American minority cultures and a variety of other cultures. It is also not entirely unheard of in American mainstream culture. For example, this method is used to train young children to use politeness routines such as "please" and "thank you", general greetings such as "Hello, how are you?" and "I'm fine", and holiday routines, such as "trick or treat" (Gleason \& Weintraub, 1977). Snow (1977) noted that adults began to expect children not only to respond, but to make appropriate responses by the time the children were 18 months old. Appropriate responses were elicited by the mothers via direct instruction in three contextssoliciting the names of people, correcting mislabelings, and eliciting polite forms. Indeed, politeness prompts have been found in other American cultures, including the working-class Americans in South Baltimore (Miller, 1982) and MexicanAmericans in California (Eisenberg, 1982). In mainstream culture, direct teaching is mainly restricted to politeness routines. In many other cultures, it is used far more frequently. The literature abounds with examples of groups found to rely heavily on direct teaching devices to socialize children in to the language of their culture. Of non-American cultures, direct teaching has been reported of the Kaluli after the child produces his or her first word (Schieffelin \& Eisenberg, 1984), the Samoans (Ochs, 1982), for sons at about 4 years of age among the Kugu-Nganychara, an Australian aboriginal tribe (von Sturmer, 1980), the Kwara'ae (Watson-Gegeo \& Gegeo, 1986a $\&$ b), the Wolof of Senegal (Wills, 1977), and the Wogeo of New Guinea (Hogbin, 1946). Demuth (1986) reports on the very prominent use of direct teaching prompts to young children among the Basotho. In America, direct teaching was found to be used extensively by the working class families in South Baltimore studied by Peggy Miller (1982). It was also reported to be a device used among the Northern New Mexico Hispanics studied by Briggs (1984) once children reached about 14 months of age and Mexican immigrant families in California studied by Eisenberg (1982). Eisenberg (1990) suggests that prompting routines, in which the caregiver tells the child what to say to someone else, are most common when conversations are multiparty. While this is true for the Kaluli, Kwara'ae, and Mexican-Americans studied, in Miller's study of working-class families in South Baltimore, interactions were mostly dyadic. As widespread as this practice of encouraging children to imitate language is, there are some cultures in which the imitation of others' speech is actively discouraged, as in Italy (Ervin-Tripp \& Mitchell-Kernan, 1977).

Interestingly, although the Hanen Program explicitly discourages parents from using direct prompts to get children to talk, they strongly recommend that parents imitate their children, both verbally and nonverbally. Research has documented that the amount that a child imitates is correlated with the amount of imitating his or her parent does. That is, highly imitative parents have highly imitative, more linguistically advanced children (Folger \& Chapman, 1978; Masur, 1989; 
Snow, 1989). These findings are presaged by Fortes study of the Tallensi in Ghana (1938), who noted that adults frequently imitated the babblings of children and expected the children to repeat in return. Blount (1972) noted that mutual imitation was characteristic of Luo parent-child interaction when the children were between 9 and 14 months old. So, while not advocating direct teaching, the Hanen Program accomplishes basically the same thing indirectly by asking parents to imitate their children. It gets children to imitate.

Observation: A number of cultures believe that language, as with other skills, is acquired by observation. As such, the ability to learn language is not tied to any overt production of speech. This has been reported of the Inuit in Northern Canada studied by Crago (1990b), the rural Louisiana Blacks studied by Ward (1971), and the Athabaskans studied by the Scollons (1981).

Multiple approackes. While some cultures may exhibit a strong tendency to emphasize one of the foregoing methods of teaching language to children, the Kwara'ae seem to believe that the best and fastest way to teach children language is multifaceted. In their culture we witness, first of all, lots of talk to children: talk that contains many simplifications. The Kwara'ae encourage child initiations. They also use routines and direct teaching to facilitate language development.

\section{LANGUAGE SOCIALIZATION RESEARCH: IMPLICATIONS FOR SLPB USING THE HANEN PROGRAM}

Rees and Gerber (1992) provide an apt conclusion to the foregoing discussion of how cultural beliefs and values shape interaction in the opening sentence of their recent article. "For practitioners whose fascination with language has led them to language disorders as a field of study and a professional commitment, language in use has turned out to be of bottomless complexity and, yet, of central importance" (p.15). Of central importance, indeed! The task before us now is to apply this growing body of information in a manner that makes our clinical interventions ever more effective. Several ways in which we might begin to do so are ioffered below.

1.-Become aware of our own cultural biases. First and foremost, professionals must begin to consciously recognize their own "invisible culture" (Crago, 1992) and hence their own cultural biases. Cheng (1989) states that "it is of utmost importance that service providers make a critical examination of their world view, values, beliefs, way oflife, communication style, learning style, cognitive study, and personal life history" (pp. 7-8). Rice (1986) provides the concrete example of tolerance for dirt. While this may on the surface seem irrelevant to implementing the Hanen Program, one of my graduate classes had a long discussion about how they felt about visiting a family who had very different cleanliness standards from their own. As a visiting clinician recounted her uncontrollable squeal in reaction to a rat on the floor in one home, one student openly admitted that she simply could not tolerate such a situation. Obviously there are many, many more biases we unconsciously harbor that could potentially interfere with our effective service delivery as professionals. Uncovering them is not a simple task.

Just as children are socialized into a given culture, professionals are likewise socialized into a professional culture. And in many ways, asking professionals to become self-aware is in itself a cultural violation, since it has clearly not been a part of their professional socialization. "What is missing, or else minimally encountered, in both graduate programs and staff development training is a focus upon the person who is the helper" (Krill, 1990, p. 12). And yet, the need for selfawareness among professionals has become glaringly apparent to me as we have begun working with families of handicapped infants and toddlers.

2 - Become cross-cultural communicators. Much of the research I have reviewed poignantly points out the very different ways in which interaction may be structured and interpreted, even among people who speak the same language. To be effective, clinicians clearly need to be aware of these potential differences. In massively polyglot societies such as the United States, it is clearly unreasonable to expect clinicians and educators to be fluent in vast numbers of languages. In working with families who speak different languages from ourselves, knowledge about other cultural communication patterns would help by at least attenuating potential cultural barriers to communication.

3-Learn about each family's communication patterns. A danger inherent in the type of review provided here is that it can rather ironically lead to stereotyping members of various cultural groups. Ochs (1986) reminds us that "cross-cultural differences turn out to be differences in context and/or frequency of occurrence" (p. 10). Furthermore, the caveat to remember that cultural trends do not ever define all members of a culture are voiced over and over again in the literature. We are asked to pay heed to the fact that no culture is a monolith (Schieffelin \& Ochs, 1986b); that "variation exists in communities, families, and individuals" (Crago, 1992, p. 30); that there is "tremendous individual variation within each group" (Miller, 1982, p. 14); "that what may appear to the outsider as one cultural group (e.g., Asians) with one set of practices may, in fact, have numerous subgroups with substantially different belief systems, political and economic histories, and cultural patterns of communication" (Crago \& Cole, 1991, p. 111). Perhaps this warning is best summed up by Rice who says, "Each child's family constitutes a cultural entity" (1986, p. 267).

How do we go about ascertaining the structure of communication within any particular family? Westby (1990) offers many suggestions on ethnographic interviewing as one technique. Obviously, observing the family interacting is also invaluable (e.g., Andrews \& Andrews, 1990).

4 -Culturally situate the notion of a disorder or delay. Saville-Troike notes that "any study of language pathologies outside one's own speech community must include culturespecific information on what is considered 'normal' and 'aberrant' performance with the other group" $(1982$, p. 9). For example, Matsuda (1989) discusses how in most Asian cultures, only physical disabilities are considered to be disabilities. In this case, a serious delay in other domains of development may be denied, and the sensitive clinician would need to be aware of such a tendency to deal with families holding such beliefs. From a quite different perspective, there may sometimes be a tendency to see a disorder where none in fact exists if the communication patterns of the culture are taken into account. We might, for example, diagnose as languagedelayed a reticent Native American or Asian-American child (Crago \& Cole, 1991). However, here we must be extremely careful not to go to the opposite extreme and "conclude that there is no disorder when one indeed exists" (Harris, 1985 , p. 43).

5 - Make instruction culturally congruent. Andrews and Andrews (1990) suggest that intervention with families will be efficacious only if they are fitted to current family structure. Supporting, if somewhat tangential, research can be found in school studies. When school instruction is made culturally congruent, children from minority cultures are shown to be 
competent learners and communicators (e.g., Erickson \& Mohatt, 1982; Heath, 1982; Hu-Pei Au, 1980; Kawakami \& Hu-Pei Au, 1986; Vogt, Jordan \& Tharp, 1987). And, the reverse is also true - penalization results from discontinuities between home and school cultures (e.g., Boggs, 1985; Durnate \& Ochs, 1988; Erickson, 1987; Heath, 1983; Philips, 1983; Tharp et al., 1984).

6 - Offer parents option to learn code-switching. Schools are institutions that reflect and reinforce values and beliefs of the mainstream culture. We know that mainstream interaction patterns best prepare children for the school environment, and best ensure their continued academic success (see Heath, 1983, for example). While we should certainly begin our interventions by gearing them to current family structure, we would likely be trying to move the family in a clearly specified direction - toward mainstream patterns of interaction. A failure to do so might diminish the nonmainstream child's chances for academic success - an outcome that would clearly violate our own basic equal opportunity cultural value. How can we reconcile this dilemma? We want on the one hand to respect the family as it is. That entails accepting all of their values and beliefs, including those that impact upon communication patterns. And yet, the child's chances for success are also of paramount importance to us. Our only choice, it seems to me, is to discuss this matter with parents in an open and honest manner. It would then be their choice, not ours, regarding whether or not they wished to pursue a parent training such as that offered by the Hanen Program. The goals of the program, including its cultural biases, would then be explicitly chosen or eschewed by the family rather than unconsciously imposed by the professional. If our mainstream patterns of interaction with young children are simply too much at odds with the values of the family we are serving, we might alternatively suggest that mainstream interaction patterns be taught and practised in a very constrained context. The final decision on whether or not they wish to become bi-cultural, however, must rest with the family and must also be genuinely supported by the clinician.

7 - Have clinician act as language socializer. There may be instances where the family is unwilling or perhaps unable to socialize their own child in a manner that will facilitate success in our mainstream culture. A program such as Hanen would obviously be an inappropriate intervention for them. In such cases, however, the clinician could offer the option of serving as a representative of the dominant culture. As such, the clinician would work directly with the child to foster the child's ability to code-switch from nonmainstream to mainstream patterns of interaction (Rice, 1986). Crago (1992), however, suggests that the code-switching option would work more successfully when children's metalinguistic skills are better developed, which generally occurs in the middle childhood years. Crago's caution seems relevant if the clinician were to teach such code-switching to the child as a consciously implemented set of rules. It seems entirely possible, however, to foster code-switching skills in much younger children if conscious approaches are not employed. As such, the clinician could use a mainstream pattern of interaction with the child, who would gradually internalize this new interactional system, even though it differed from patterns of interaction with her or his parents.

8 - Inform teachers about their children's culturally determined patterns of interaction. As the classroom collaborative model of service delivery continues to gain in popularity in the United States, the opportunities for SLPs to impact a child's communicative experiences in the classroom increase exponentially. Clearly, children will benefit if teachers are made aware of the culturally determined differences in their interaction patterns. This is an obvious role the SLP can serve.

\section{CONCLUSION}

As Westby (1990) noted, "traditional educational and therapeutic intervention models have not been effective with minority populations" (p. 110). And yet, in the next decade, as much as one-third of the caseload of audiologists and SLPs in the United States will be children from Black, Hispanic, and Native American cultures (Cole, 1989; Crago, 1990a; Shewan, 1988). If our services are to be effective, we must find ways to make them more culturally sensitive. The foregoing discussion of the Hanen Early Language Parent Program offers but one example of the kinds of cultural biases to be found in even the very best of current clinical interventions. Just as we have much to learn from research on language socialization in nonmainstream cultures, so too can we learn from the nonmainstream families we serve. To quote the Mexican novelist Carlos Fuentes from his recent cultural history of Spain and Latin America:

People and their cultures perish in isolation, but they are born and reborn in contact with other men and women, with men and women of another culture, another creed, another race. If we do not recognize our humanity in others, we shall not recognize it in ourselves.

from The Buried Mirror by Carlos Fuentes (1992)

\section{REFERENCES}

Anderson, E. \& Kekelis, L. (1986). Siblings' contribution to the interactional competence of blind children. Quarterly Newsletter of the Laboratory of Comparative Human Cognition.

Andrews, J. \& Andrews, M. (1990). Family based treatment in communicative disorders. Sandwich, Illinois: Janelle Publications.

Beebe, B., Jaffe, J., Feldstein, S., Mays, K. \& Alson, D. (1985). Matching timing: The application of an adult dialogue model to motherinfant vocal and kinesic interactions. In T. Field, (Ed)., Infant social perception. Norwood, NJ: ABLEX.

Bellinger, D. \& Gleason, J. (1982). Sex differences in parental directives to young children. Sex Roles, 8, 1123-1139.

Birdwhistell, R. (1974). The language of the body: The natural environment. In A. Silverstein, (Ed)., Human communication: Theoretical explorations. New York: John Wiley.

Blanchard, E. (1983). The growth and development of American Indian children and Alaskan native children. In G. Powell, (Ed)., The psychological development of minority group children. New York: Brunner/Mazel.

Bloom, L. (1970). Language development: Form and function in emerging grammar. Cambridge, MA: MIT Press.

Blount, B. (1972). Aspects of Luo socialization. Language in Society, 1 , $235-248$.

Blount, B. (1977). Ethnography and caretaker-child interaction. In C. Snow, \& C. Ferguson, (Eds)., Talking to children: Language input and acquisition. Cambridge: Cambridge University Press.

Boggs, S. (1985). Speaking, relating, and learning: A study of Hawaiian children at home and at school. Norwood, NJ: ABLEX.

Briggs, C. (1984). Learning how to ask: Native meta communicative competence and the incompetence of field workers. Language in Society, 13, 1-28.

Brown, R. (1973). A first language: The early stages. Cambridge, MA: Harvard University Press.

Brown, R. (1977). Introduction. In C. Snow, \& C. Ferguson, (Eds)., Talking to children: Language input and acquisition. Cambridge: Cambridge University Press.

Caudill, W.\& Weinstein, H. (1969). Maternal care and infant behavior in Japan and America. Psychiatry, 32, 12-43.

Cheng, L. (1989). Service delivery to Asian/Pacific LEP children: A cross-cultural framework. Topics in Language Disorders, 9(3), 114. 
Clency, P. (1986). The acquisition of communicative style in Japanese. In B. Schieffelin, \& E. Ochs, (Eds)., Language socialization across In B. Schiefferidge: Cambridge University Press.

cultures. Camb . Eluribus unum pluribus: Multicultural imperatives for the 1990s and beyond. Asha, 31, 65-70.

Cskimos, Chicanos, Indians. Boston: Little, Brown, $\&$ Co.

Constable, C. (1986). The application of scripts in the organization of language intervention contexts. In K. Nelson, (Ed)., Event know ledge: Structure and function in development. Hillsdale, NJ: Lawrence Erlbaum.

Crago, M. (1990a). Professional gatekeeping: The multicultural, multilingual challenge. Communique, 10-13.

competence in Inuit children: Implications for speech-language pathology. Journal of Childhood Communication Disorders, 13 (1), 73-83.

Crago, M. (1992). Ethnography and language socialization: A crosscultural perspective. Topics in Language Disorders, 12 (3), 28-39.

Crago, M. \& Cole, E. (1991). Using ethnography to bring children's communicative and cultural worlds into focus. In T. Gallagher, (Ed)., Pragmatics of language: Clinical practice issues. San Diego: Singular.

Daly, J. \& McCroskey, J. (1984). Avoiding communication: Shyness, reticence, and communication apprehension. Beverly Hills, CA SAGE Publications.

Demuth, K. (1986). Prompting routines in the language socialization of Basotho children. In B. Schieffelin, \& E. Ochs, (Eds)., Language socialization across cultures. Cambridge: Cambridge University Press.

Dumont, R. (1972). Learning English and how to be silent: Studies in Sioux and Cherokee classrooms. In C. Cazden, D. Hymes, \& V. John, (Eds)., Functions of language in the classroom. NY: Teachers College Press.

Dunst, C., Lowe, L. \& Bartholomew, P. (1989-1990). Contingent social responsiveness, family ecology, and infant communicative competence. National Student Speech Language Hearing Association Journal, 17, 39-49.

Duranti, A. \& Ochs, E. (1988). Literacy instruction in a Samoan village. In E. Ochs, (Ed)., Culture and language development: Language acquisition and language socialization in a Samoan village. Cambridge: Cambridge University Press.

Eisenberg, A. (1982). Language development in cultural perspective: Talk in three Mexican homes. Unpublished Ph.D. dissertation. University of California, Berkeley.

Erickson, F. (1987). Transformation and school success: The politics and culture of educational achievement. Anthropology and Educational Quarterly. 18, 335-357.

Erickson, F. \& Mohatt, G. (1982). Cultural organization of participation structures in two classrooms of Indian students. In G. Spindler, (Ed)., Doing the ethnography of schooling: Educational anthropology in action. Orlando, FL: Holt, Rinehart, \& Winston.

Ervin-Tripp, S. \& Mitchell-Kernan, C. (1977). Child discourse. NY Academic Press.

Fischer, J. (1970). Linguistic socialization: Japan and the United States. In R. Hill, \& R. Konig, (Eds)., Families in East and West. The Hague: Mouton.

Folger, J. \& Chapman, R. (1978) A pragmatic analysis of spontaneous imitations. Journal of Child Language, 5, 25-38.

Fortes, M. (1938). Social and psychological aspects of education in Taleland, Africa, 11 (4), 14-74.

Freedman, D. (1979, January). Ethnic differences in babies. Human Nature Magazine, 36-43.

Fuentes, C. (1992). The buried mirror: Reflections on Spain and the New World. Boston: Houghton Mifflin.

Girolametto, L., Greenberg, J. \& Manolson, A. (1986). Developing dialogue skills: The Hanen early language parent program. Seminars in Speech and Language, 7 (4), 367-381.

Gleason, J. \& Greif, E. (1983). Men's speech to young children. In B. Thorne, C. Kтаmerae, \& N. Henley, (Eds)., Langrage, gender, and society. Rowley, MA: Newbury House.

Gleason, J. \& Weintraub, S. (1976). The acquisition of routines in child language. Language in Society, 5, 129-136.

Goldberg, S. (1977). Social competence in infancy: A model of parentinfant interaction. Merrill-Palmer Quarterly, 23, 163-177.

Golinkoff, R. \& Ames, G. (1979). A comparison of fathers' and mothers' speech to their young children. Child Development, 50 , $28-32$.

Hall, E. (1976). Beyond culture. New York: Anchor Press/Doubleday.

Harkness, S. (1977). Aspects of social environment and first language acquisition in rural Africa. In C.Snow, \& C. Ferguson, (Eds)., Talk- ing to children: Language input and acquisition. Cambridge: Cambridge University Press.

Harris, G. (1985). Considerations in assessing English language performance of Native American children. Topics in Language Disorders, 5 (4), 42-52.

Heath, S. B. (1982). Ethnography in education: Defining the essentials. In P. Gilmore, \& A. Glatthorn, (Eds)., Children in and out of school: Ethnography and education. Washington, D.C.: Center for Applied Linguistics.

Heath, S. B. (1983). Ways with words: Language, life, and work in communities and classrooms. Cambridge: Cambridge University Press.

Heath, S. B. (1989). The learner as cultural member. In M. Rice, \& R. Schiefelbusch, (Eds)., The teachability of language. Baltimore: Paul Brookes.

Hogbin, H. (1946). A New Guinea childhood: From weaning till the eighth year in Wogeo. Oceania, 16 (4), 275-296.

$\mathrm{Hu}$-Pei Au, K. (1980). Participation structures in a reading lesson with Hawaiian children: Analysis of culturally appropriate instructional events. Anthropology and Education Ouarterly, 11, 91-115.

John, V. (1972). Styles of learning--styles of teaching: Reflections on the education of Navajo children. In C. Cazden, D. Hymes, \& V. John, (Eds)., Functions of language in the classroom. NY: Teachers College Press.

Kawakami, A., \& Hu-Pei Au, K. (1986). Encouraging reading and language development in cultural minority children. Topics in Language Disorders, 6 (2), 71-80.

Krill, D. (1990). Practice wisdom: A guide for hel ping professionals. Newbury Park, CA: SAGE

Leiderman, P. \& Leiderman, G. (1974). Affective and cognitive consequences of polymatric care in the east African highlands. In A. Pick, (Ed)., Minnesota Symposia on Child Psychology, Vol. 8. London: Oxford University Press.

LeVine, R. (1977). Child rearing as cultural adaptation. In P. Liederman, S. Tulkin, \& A. Rosenfeld, (Eds)., Culture and infancy: Variations in the human experience. Orlando, FL: Academic Press

LeVine, R. \& LeVine, B. (1966). Nyansango: A Gusii community in Knysna. New York: John Wiley \& Sons.

Lock, A. (1981). The guided reinvention of language. London: Academic Press.

MacDonald, J. (1989). Becoming partners: From play to conversation. Chicago: Riverside Publishing

Mannle, S. \& Tomasello, M. (1987). Fathers, siblings, and the bridge hypothesis. In K. Nelson, \& A. van Kleeck, (Eds)., Children's language, Vol. 6. Hillsdale, NJ: Lawrence Erlbaum.

Manolson, A. (1985). It takes two to talk: A Hanen early language paren guide book (second revision). Toronto: Hanen Early Language Resource Center.

Masur, E. (1989). Individual and dyadic patterns of imitation: Cognitive and social aspects. In G. Speidel, \& K. Nelson, (Eds)., The many faces of imitation in language learning. New York: Springer-Verlag.

Matsuda, M. (1989). Working with Asian parents: Some communication strategies. Topics in Language Disorders, 9 (3), 45-53.

McCroskey, J. \& Daly, J. (1976). Teachers' expectations of the communication apprehensive child in the elementary school. Human Communication Research, 3 (1), 67-72.

Millar, W. (1972). A study of operant conditioning under delayed reinforce ment in early infancy. Monographs of the Society for Research in Child Development, 37, (2, Serial No. 147)

Millar, W. \& Watson, J. (1979). The effect of delayed feedback on infant learning re-examined. Child Development, 50, 747-751.

Miller, P. (1982). Amy, Wendy, and Beth: Learning language in South Baltimore. Austin, TX: University of Texas Press.

Newport, E., Gleitman, H. \& Gleitman, L. (1977). Mother, I'd rather do it myself: Some effects and non-effects of maternal speech style. In C. Snow, \& C. Ferguson, (Eds)., Talking to children: Language input and acquisition. Cambridge: Cambridge University Press.

Ochs, E., (1982). Talking to children in Western Samoa. Language in Society, 11, 77-104

Ochs, E. (1986). Introduction. In B. Schieffelin, \& E. Ochs, (Eds). Language socialization across cultures. Cambridge: Cambridge University Press.

Ochs, E. (1988). Culture and language development: Language acquisition and language socialization in a Samoan village. Cambridge: Cambridge University Press.

Ochs, E. \& Schieffelin, B. (1984). Language acquisition and socialization: Three developmental stories and their implications. In $\mathrm{R}$ Shweder, \& R. LeVine, (Eds)., Culture theory: Essays on mind, self, and emotion. Cambridge: Cambridge University Press.

Philips, S. (1983). The invisible culture: Communication in classroom and community on the Warm Springs Indian Reservation. New York: Longman. 
Ramey, C. \& Ourth, L. (1971). Delayed reinforcement of vocalization rates in infants. Child Development, 42, 291-297.

Rees, N. \& Gerber, S. (1992): Ethnography and communication: Social-role relations. Topics in Language Disorders, 12 (3), 15-27.

Rice, M. (1986). Mismatched premises of the communicative competence model and language intervention. In $R$. Schiefelbusch, (Ed)., Language competence: Assessment and intervention. San Diego: College-Hill Press.

Ryan, J. (1974). Early language development: Towards a communicational analysis. In M. Richards, (Ed)., The integration of a child into a social world. Cambridge: Cambridge University Press.

Sachs, J. (1983). Talking about the there and then: The emergence of displaced reference in parent-child discourse. In K. Nelson, (Ed)., Children's language, Vol. 4. Hillsdale, NJ: Lawrence Erlbaum.

Saville-Troike, M. (1982). The ethnography of communication: An introduction. Baltimore: University Park Press.

Schaffer, H., Collis, G. \& Parsons, G. (1977). Vocal interchange and visual regard in verbal and pre-verbal children. In $\mathrm{H}$. Schaffer, (Ed)., Studies in mother-infant interaction. London: Academic Press.

Schegloff, E. (1972). Notes on a conversational practice: Formulating place. In D. Sudnow, (Ed)., Studies in social interaction. New York: Free Press.

Schieffelin, B. (1979). Getting it together: An ethnographic approach to the study of the development of communicative competence. In E. Ochs, \& G. Schieffelin, (Eds)., Developmental pragmatics. New York: Academic Press.

Schieffelin, B. \& Eisenberg, A. (1984). Cultural variation in children's conversations. In R. Schiefelbusch, \& J. Pickar, (Eds). The acquisition of communicative competence. Baltimore: University Park Press.

Schieffelin, B. \& Ochs, E. (1986). Language socialization. Annual Review of Anthropology, 15, 163-191.

Scollon, R. \& Scollon, S. (1981). Narrative, literacy, and face in interethnic communication. Norwood, NJ: ABLEX.

Shewan, C. (1988). Omnibus survey: Adaptation and progress in times of change. Asha, 30 (8), 27-30.

Shotter, J. (1978). The cultural context of communication studies. Theoretical and methodological issues. In A. Lock, (Ed)., Action, gesture, and sumbol. London: Academic Press.

Snow, C. (1977). The development of conversation between mothers and babies. Journal of Child Language, 4, 1-22.

Snow, C. (1979). The role of social interaction in language acquisition. In A. Collins, (Ed)., Children's language and communication: 12th Minnesota symposium on child psychology. Hillsdale, NJ: Lawrence Erlbaum.

Snow, C. (1986). Conversations with children. In P. Fletcher, \& M. Garman, (Eds)., Language acquisition (2nd edition). Cambridge: Cambridge University Press.

Snow, C. (1989). Imitativeness: A trait or a skill. In G. Speidel, \& K.
Nelson, (Eds)., The many faces of imitation in language learning. New York: Springer-Verlag.

Stella-Prorok, E. (1983). Mother-child language in the natural environment. In K. Nelson, (Ed)., Children'slanguage, Vol. 4. New York: Gardner Press.

Tharp, R., Jordan, C., Speidel, G., Hu-Pei Au, K., Klein, T., Calkins, R., Sloat, K., \& Gallimore, R. (1984). Product and process in applied developmental research: Education and the children of a minority. In M. Lamb, A. Brown, \& B. Rogoff, (Eds)., Advances in developmental psychology (Vol. 3). Hillsdale, NJ: Lawrence Erlbaum.

Todd, G. \& Palmer, B. (1968). Social reinforcement of infant babbling. Child Development, 39, 591-596.

van Kleeck, A., \& Carpenter, R. (1980). The effects of children's language comprehension level on adults' child directed talk. Journal of Speech and Hearing Research, 23, 546-569.

Vogt, L., Jordan, C. \& Tharp, R. (1987). Explaining school failure, producing school success: Two cases. Anthropology and Education Quarterly, 18, 276-286.

von Sturmer, D. (1980). Rights in nurturing: The social relations of childbearing and rearing amongst the Kugu-Nganychara. Master's thesis, Australian National University, Canberra.

Ward, M. (1971). Them children: A study in language learning. Prospect Heights, Illinois: Waveland Press.

Watson-Gegeo, K. \& Gegeo, D. (1986a). Calling-out and repeating routines in Kwara'ae children's language socialization. In B. Schieffelin, \& E. Ochs, (Eds)., Language socialization across cultures. Cambridge: Cambridge University Press.

Watson-Gegeo, K. \& Gegeo, D. (1986b). The social world of Kwara'ae children: Acquisition of language and values. In J. Cook-Gumperz, W. Corsaro, \& J. Streeck, (Eds)., Children's worlds and children's language. Berlin: Mouton de Gruyter.

Wells, G. (1982). Influences of the home on language development. In A. Davies, (Ed)., Language and learning at school and home. London: Heinemann.

Werner, E. (1984). Child care: Kith, kin and hired hands. Baltimore: University Park Press.

Westby, C. (1990). Ethnographic interviewing: Asking the right questions to the right people in the right ways. Journal of Childhood Communicative Disorders, 13 (1), 101-111.

Westby, C. \& Rouse, G. (1985). Culture in education and the instruction of language learning-disabled students. Topics in Language Disorders, 5 (4), 15-28.

Williamson, S. (1979). Tamil baby talk: A cross-cultural study. Unpublished doctoral dissertation, University of Pennsylvania.

Wills, D. (1977). Culture's cradle: Social, structural, and interactional aspects of Senegalese socialization. Unpublished doctoral dissertation, University of Texas at Austin. 